\title{
A comparison of the dye-binding and fluorodinitrobenzene methods for determining reactive lysine in leaf-protein concentrates
}

\author{
BY ANN F. WALKER \\ Department of Food Science, University of Reading, London Road, Reading RG $15 A Q$
}

(Received 15 February 1979 - Accepted 25 June 1979)

\begin{abstract}
I. Twenty-eight leaf-protein concentrate (LPC) samples, subjected to different thermal treatments, were produced from five curd batches. For these samples, the fluorodinitrobenzene (FDNB)-reactive lysine values gave closer agreement with dye-binding lysine (DBL) than with the dye-binding capacity (DBC).

2. No relationship was established between the dye-bound-after-propionylation (DBAP) and the histidine + arginine value.

3. Comparison of dye-bound-protein values with those for tungstic-acid-precipitated nitrogen $\times 6 \cdot 25$ for the LPC samples showed the heat-damaged samples to lie below the regression line for the other samples.

4. Reactive-lysine values by dye-binding and by FDNB methods correlated well with total lysine, but the slopes of the regression line indicated closer agreement for values for samples not damaged by heat.

5. The correlation coefficients between $\mathrm{DBC}$ and total basic amino acids, DBC and histidine + arginine + $\mathrm{DBL}$, and DBC and histidine + arginine + FDNB-reactive lysine were similar.

6. There was no correlation between the lightness of colour of the LPC samples and the availability of lysine.
\end{abstract}

In this study, samples of leaf-protein concentrate (LPC) were prepared using different curddrying techniques and other heat treatments. These samples were used to investigate the effect of thermal treatment on the availability of lysine by two methods. LPC undergoes several processes in production (Pirie, I971), but Byers (1971) found that damage to lysine occurred only during the heat-coagulation stage. It was shown previously (Walker, 1979) that even careful preparation of LPC results in samples in which some lysine ceases to be available (reactive by the dye-binding lysine (DBL) method). Using the protein efficiency ratio assay with rats (gain in body-weight per g protein), Shurpalekar et al. (1966) and Bickoff et al. (1975) found considerable losses of nutritional value on thermal drying of LPC curd as compared with freeze-drying. Henry (1964), who determined the biological value and true digestibility of LPC samples, found that hot-air drying in particular reduced the true digestibility of LPC, and Allison et al. (1973) showed, using a deamination method for available lysine, that these values correlated, significantly, with in vivo digestibility values for LPC samples.

The DBL method, described previously (Walker, I979), is here compared with the direct measurement of fluorodinitrobenzene (FDNB)-reactive lysine (Carpenter, 1960), using the modification of Booth (I97I). The FDNB-reactive lysine method is an established chemical method for detecting processing damage and has been correlated with the chick assay (Carpenter \& Woodham, 1974), although it does not correlate so well with the rat assay. There is evidence that biological assay using chicks is not directly comparable to that using rats (Fisher, I974), which are the laboratory animals of choice for comparison of human nutrient requirements. Ford (1964) and Henry \& Ford (1965) found that the availability of lysine for various food materials (including an LPC sample), as measured by a microbiological procedure was more consistent with the rat assay than that measured by the FDNB reaction. Boctor \& Harper (1968) compared the FDNB-reactive lysine value with the rat assay and showed that available lysine values for heat-treated foods varied greatly with the method of assay used. However, the number of samples that they investigated was limited, 
owing to the laborious nature of both the FDNB and rat assay methods, particularly the latter. For autoclaved egg albumin, the FDNB-reaction gave a value of 0.56 for lysine availability and rat growth assay a corresponding value of 0.20 . Similar but smaller differences were obtained for autoclaved beef muscle. Boctor \& Harper (I968) postulated that sugars bound to lysine interfere with the hydrolytic activity of digestive enzymes; thus FDNB-reactive lysine values may underestimate the extent of availability. If this is so, it may account for the reports of FDNB-reactive lysine being found in rat faeces (Hurrell et al. 1976). Therefore, correlation between the animal assay and the FDNB-reactive lysine method is not straightforward but, nevertheless, the FDNB method remains a good indicator of processing damage and there is information based on this method from many laboratories for many different foods. Jokinen \& Reineccius (1976) examined several chemical methods for the determination of available lysine (excluding the DBL method) and found that the Booth (I97I) modification of the Carpenter ( 1960 ) method gave comparable results in their laboratories to other values reported for the same food materials. In addition to these nutritional considerations, the disadvantages of the FDNB method are the period required for assay, the small number of samples that can be dealt with simultaneously and the considerable technical skill required. The DBL method offers advantages on these latter considerations.

In this paper reactive lysine values determined by the FDNB and DBL methods are also compared with total lysine determined by amino-acid analysis of acid hydrolysates. Experiments on the behaviour of the amino acids in the presence of quinones (Cranwell \& Haworth, 197I) and humic acid (Perry \& Adams, 197I) during acid hydrolysis show that an amino acid residue in which the amino group has become involved in bond formation is released only in part under the usual conditions of protein hydrolysis. As lysine in particular takes part in the reactions, it would be expected that total lysine values calculated from ionexchange chromatography of acid hydrolysates would yield low values.

Darkening of the colour of LPC occurs during processing, and this is thought to be due to the reactions of the phenolic compounds of LPC (Bray \& Humphries, 1978). The extent of darkening was measured to determine whether it could be used as an indicator of nutritional damage to LPC samples, when compared with the DBL and FDNB techniques.

Mossberg (1966) used dye-binding capacity (DBC) (with $\mathrm{Cl}$ Acid Orange 10) as an indicator of processing damage, but Lea \& Hannan ( 1950), who also used Acid Orange 10, noted that DBC did not indicate early Maillard damage. Similarly, Hurrell \& Carpenter (1975) found, using CI Acid Orange 12 in comparison with the FDNB-reactive lysine, that DBC was insensitive to early Maillard damage, but was a good indicator of late Maillard damage. Both FDNB-reactive lysine and DBL were determined for some food samples by Hurrell \& Carpenter $(1976,1978)$ and show close agreement. The DBL method used by these authors was similar to that described here and used the same dye-buffer reagent, but the samples were mixed with the dye for $10 \mathrm{~min}$ in a wet-milling process, using specially designed equipment.

\section{EXPERIMENTA L}

\section{Preparation of $L P C$ samples}

The LPC samples studied are described in Table I. The control samples were the same as those described previously (Walker, 1979). All samples were prepared during the 1975 and 1976 seasons from five batches of leaf juice by the method described previously (Walker, 1979). The juice extraction equipment used was a large-scale pulper and press (Davys \& Pirie, I960, 1965) for LPC batches nos. 1, 2 and 5 and a screw press (Bentalls 'Protessa' screw press; E. H. Bentalls and Co. Ltd, Maldon, Essex) for batches nos. 3 and 4 . For each curd batch, a sample was dried overnight in a Vickers freeze-drier (Vickers-Armstrong 
Table I. Details of leaf-protein concentrate (LPC) samples used

\begin{tabular}{|c|c|c|c|}
\hline $\begin{array}{l}\text { Batch } \\
\text { no. }\end{array}$ & Leaf source & $\begin{array}{l}\text { Sample } \\
\text { no. }\end{array}$ & Drying technique used \\
\hline I & Lucerne (Medicago sativa $\mathrm{L}$.) & $\begin{array}{r}3 \\
12 \\
13 \\
14 \\
15 \\
16 \\
17\end{array}$ & $\begin{array}{l}\text { FD } \\
\text { RT } \\
50^{\circ} \text {, forced-air oven, overnight } \\
90^{\circ} \text {, forced-air oven, overnight } \\
90^{\circ} \text {, V } \\
\mathrm{FD} \text {, then heated } 110^{\circ}, 16 \mathrm{~h} \text { at } 100 \mathrm{~g} \text { moisture } / \mathrm{kg} \\
\mathrm{FD} \text {, then heated } 110^{\circ}, 24 \text { h at } 100 \mathrm{~g} \text { moisture } / \mathrm{kg}\end{array}$ \\
\hline 2 & Lucerne & $\begin{array}{l}11 \\
18 \\
19 \\
20 \\
21\end{array}$ & $\begin{array}{l}\text { FD } \\
50^{\circ} \text {, forced-air oven, overnight } \\
90^{\circ}, \text { forced-air oven, overnight } \\
90^{\circ}, \mathrm{V} \\
\text { Evaporated under reduced pressure }\end{array}$ \\
\hline 3 & $\begin{array}{l}\text { Ryegrass (Italian) } \\
\text { (Lolium multiflorum L. var. } \\
\text { RVP) }\end{array}$ & $\begin{array}{l}1 \\
4 \\
5 \\
6 \\
7 \\
8 \\
9\end{array}$ & $\begin{array}{l}\mathrm{FD} \\
\mathrm{RT} \\
50^{\circ} \text {, forced-air oven, overnight } \\
90^{\circ} \text {, forced-air oven, overnight } \\
90^{\circ} \text {, V } \\
\mathrm{FD} \text {, then heated } 110^{\circ}, 16 \mathrm{~h} \text { at } 100 \mathrm{~g} \text { moisture } / \mathrm{kg} \\
\mathrm{FD} \text {, then heated } 110^{\circ}, 24 \mathrm{~h} \text { at } 100 \mathrm{~g} \text { moisture } / \mathrm{kg}\end{array}$ \\
\hline 4 & Ryegrass (Italian) & $\begin{array}{r}3 \\
10 \\
11 \\
12\end{array}$ & $\begin{array}{l}\text { FD } \\
50^{\circ} \text {, forced-air oven, overnight } \\
90^{\circ} \text {, forced-air oven, overnight } \\
90^{\circ}, \mathrm{V}\end{array}$ \\
\hline 5 & $\begin{array}{l}\text { Fescue (Festuca arundinacea L. } \\
\text { var. Alta) }\end{array}$ & $\begin{array}{l}2 \\
3 \\
4 \\
5 \\
6\end{array}$ & $\begin{array}{l}\text { FD } \\
\text { RT } \\
50^{\circ} \text {, forced-air oven, overnight } \\
90^{\circ} \text {, forced-air oven, overnight } \\
90^{\circ}, \mathrm{V}\end{array}$ \\
\hline
\end{tabular}

FD, freeze-dried, overnight (see p. 456); RT, curd spread thinly and dried at room temperature over a period of $2 \mathrm{~d}$; $\mathrm{V}$, vacuum oven overnight.

(South Marston) Ltd, South Marston Works, Swindon), using a shelf heat of $30^{\circ}$. This was used as a control for other samples within the same batch which were dried or heated by different techniques. Samples were ground and stored as previously described (Walker, 1979).

\section{Analysis of LPC samples}

Dye-binding capacity (DBC), dye-bound-after-propionylation (DBAP), DBL, protein and amino acids (including total lysine) were measured and values calculated as described previously (Walker, I979).

FDNB-reactive lysine. This was measured by the direct estimation of FDNB-reactive lysine as described by Booth ( $197 \mathrm{I}$ ). As the molecular weight of the lysine residue had been used for the calculation of DBL and total lysine, this value was also used for the calculation of FDNB-reactive lysine, rather than the molecular weight of the amino acid. The FDNBreactive lysine value was corrected for loss of FDNB-reactive lysine by using the correction factor 1.09 (Roach et al. 1967) for materials low in carbohydrate.

Colour. This was measured using a Hunter Colour Difference Meter which measures colour in terms of the $L, a, b$ colour solid $((L)$, lightness, where 0 is black and 100 is white; $(-a)$, greenness; $(+b)$, yellowness). Only lightness of colour is recorded here. The LPC powders were prepared for the instrument by pressing a sample between two Petri dishes 


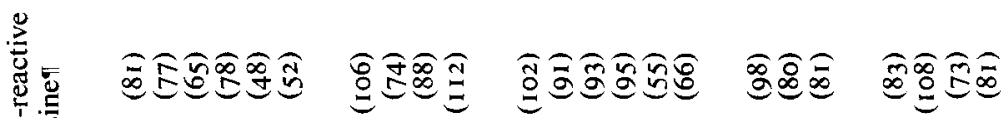

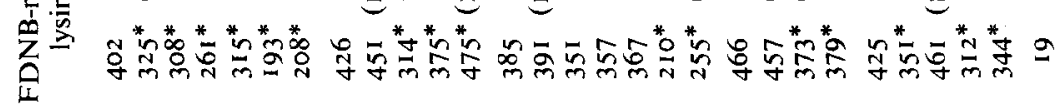

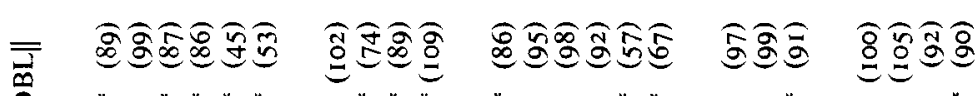

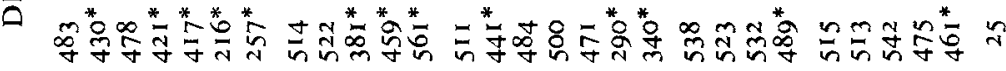

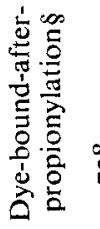

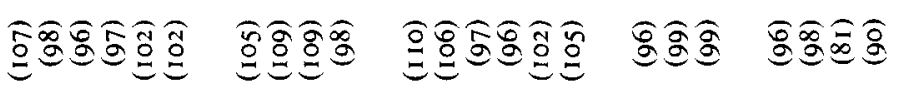

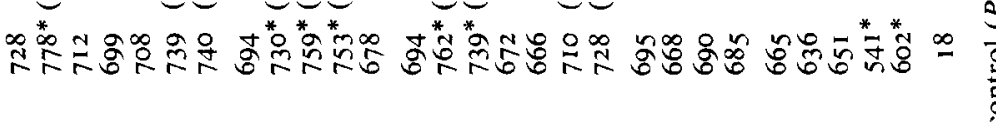

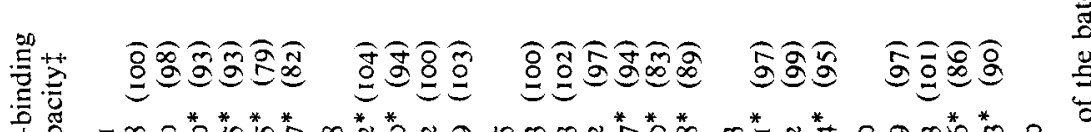
它

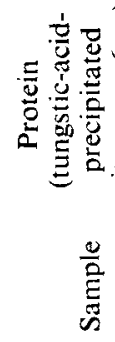

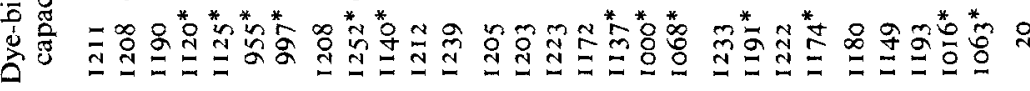

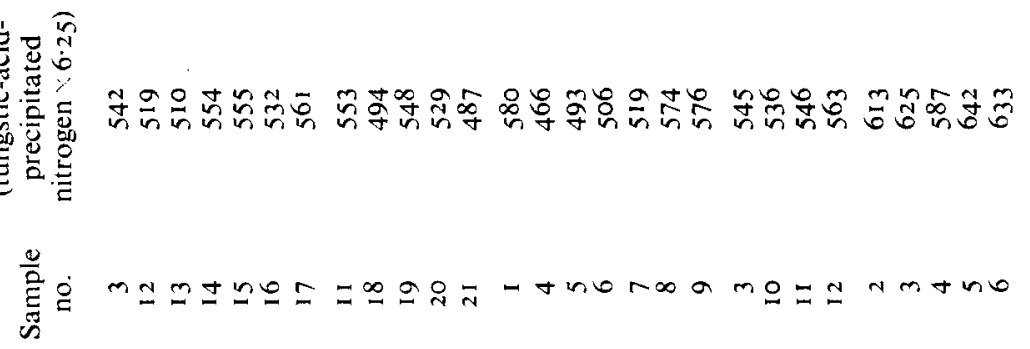


to form a flat cake. The machine was calibrated against standard black and white tiles, and two determinations were made for each sample.

A preliminary plot was made of all paired data where relationships were being investigated. In all cases where a relationship clearly existed it was substantially linear over the range studied, and correlation coefficients were, therefore, determined.

\section{RESULTS AND DISCUSSION}

Table 2 shows results for protein, DBC, DBAP, DBL and FDNB-reactive lysine for the 28 LPC samples studied. Each observation is the mean of duplicate observations. An estimate of the standard error of replication of these observations, based on ten duplicate samples of each is also given in Table 2.

The mean value for the FDNB-reactive lysine was approximately $100 \mathrm{mmol} / \mathrm{kg}$ protein lower than the DBL value. The correlation coefficient $(r)$ between FDNB-lysine and DBL values was $0.90(n 28)$ and the regression equation was $y=-15.5+0.81 x$, with $y==$ FDNBlysine (mmol $/ \mathrm{kg}$ protein) and $x=\mathrm{DBL}(\mathrm{mmol} / \mathrm{kg}$ protein). The residual variance of the regression was $\mathrm{I} 300$.

A regression analysis of the FDNB-reactive lysine and DBC values gave $r=0.83(n 28)$ and the regression equation $y=-571.5+0.80 x$, where $y=$ FDNB-reactive lysine ( $\mathrm{mmol} / \mathrm{kg}$ protein) and $x=\mathrm{DBC}(\mathrm{mmol} / \mathrm{kg}$ protein). The residual variance of the regression was 2000 , which was not significantly different from the residual variance of the regression of DBL and FDNB-reactive lysine. However, the use of the latter regression equation allows more precision in the prediction of FDNB-reactive lysine, and the lower residual variance of this regression is in accordance with results reported by Hurrell \& Carpenter (1978).

In Table 2 the DBC, DBAP and FDNB-reactive lysine values are also expressed as percentages of the corresponding value for the freeze-dried control for that batch. All batches showed some samples in which DBC was significantly decreased $(P<0.05)$ when compared with the freeze-dried control. However, the decrease due to a particular treatment was not consistent for all LPC batches. Previously (Fig. 4; Walker, 1979) DBC was shown to correlate highly $(r 0.98, n 20)$ with the protein content (tungstic-acid-precipitated $\mathrm{N} \times 6.25$ ) for undamaged LPC samples. DBC results (in appropriate units) from Table 2 were compared with this regression line. Values for samples which had received the most severe heat treatment lie furthest below this regression line. This is to be expected, as DBC is the dye bound to the basic amino acids including lysine (Hurrell \& Carpenter, 1975). This effect of thermal damage of a food sample on its DBC has been noted previously (Mossberg, 1966).

The DBAP values showed that there was little significant difference between samples dried by different drying techniques and their batch controls. In some instances (e.g. lucerne nos. 18,19 and 20 ) there were significant increases which cannot be explained. There was no correlation between DBAP and arginine +histidine $(r-0.18, n 28)$, which was unexpected, as in principle the histidine + arginine groups are all that remain for binding dye after reactive lysine has been blocked. This may imply that the DBAP value includes nonspecific binding sites. The effects of the presence of food components other than proteins on the DBL values are not yet known.

The DBL values showed significant differences for many of the heat-treated LPC samples, when compared to their batch controls, and most of those which were significantly different from the batch control for the DBL value were also significantly different from the batch control for the FDNB-reactive lysine value. One LPC sample (lucerne no. 2I) showed a significant increase in available lysine in relation to the batch control by both methods. This sample had been dried at room temperature by evaporation under reduced pressure, and was the only sample to be dried in this manner. Four of the heat-damaged samples 
Table 3. Basic amino acids, glutamic acid and aspartic acid (mmol/kg protein)* of twenty-eight leaf-protein concentrate samples subjected to different heat treatments $\dagger$

(All results are the mean of analyses of duplicate hydrolysatesł; values in parentheses are the percentages of the batch control value)

\begin{tabular}{|c|c|c|c|c|c|c|c|}
\hline $\begin{array}{l}\text { Batch } \\
\text { no. }\end{array}$ & Leaf source $\dagger$ & $\begin{array}{c}\text { Sample } \\
\text { no. }+\end{array}$ & $\begin{array}{l}\text { Aspartic } \\
\text { acid }\end{array}$ & $\begin{array}{l}\text { Glutamic } \\
\text { acid }\end{array}$ & Lysine & Histidine & Arginine \\
\hline $\mathbf{I}$ & $\begin{array}{l}\text { Lucerne (Medicago } \\
\text { sativa } \mathbf{L} \text {.) }\end{array}$ & $\begin{array}{r}3 \\
12 \\
13 \\
14 \\
15 \\
16 \\
17\end{array}$ & $\begin{array}{l}858 \\
889 \\
892 \\
857 \\
865 \\
868 \\
862\end{array}$ & $\begin{array}{l}880 \\
936 \\
864 \\
829 \\
876 \\
906 \\
903\end{array}$ & $\begin{array}{ll}523 & \\
497 & (95) \\
483 \S & (92) \\
448 \S & (86) \\
461 \S & (88) \\
371 \S & (71) \\
375 \S & (72)\end{array}$ & $\begin{array}{l}206 \\
200 \\
184 \\
192 \\
198 \\
187 \\
191\end{array}$ & $\begin{array}{l}463 \\
41 \text { I } ~ \\
426 \\
428 \\
433 \\
3968 \\
410 \S\end{array}$ \\
\hline 2 & Lucerne & $\begin{array}{l}11 \\
18 \\
19 \\
20 \\
21\end{array}$ & $\begin{array}{l}837 \\
829 \\
8858 \\
909 \S \\
9068\end{array}$ & $\begin{array}{l}835 \\
862 \\
887 \\
885 \\
851\end{array}$ & $\begin{array}{lr}544 & \\
553 & (102) \\
497 \S & (91) \\
494 \S & (91) \\
541 & (99)\end{array}$ & $\begin{array}{l}215 \\
209 \\
202 \\
193 \\
193\end{array}$ & $\begin{array}{l}422 \\
451 \\
414 \\
418 \\
420\end{array}$ \\
\hline 3 & $\begin{array}{l}\text { Ryegrass (Italian) } \\
\text { (Lolium multiflora } \\
\text { L. var. RVP) }\end{array}$ & $\begin{array}{l}\text { I } \\
4 \\
5 \\
6 \\
7 \\
8 \\
9\end{array}$ & $\begin{array}{l}853 \\
801 \& \\
832 \\
833 \\
855 \\
824 \\
816\end{array}$ & $\begin{array}{l}921 \\
875 \\
862 \\
881 \\
906 \\
960 \\
902\end{array}$ & $\begin{array}{lr}499 & \\
534 \S & (107) \\
505 & (101) \\
481 & (96) \\
493 & (99) \\
397 \S & (80) \\
435 \S & (87)\end{array}$ & $\begin{array}{l}201 \\
195 \\
191 \\
187 \\
184 \\
175 \\
193\end{array}$ & $\begin{array}{l}43 \text { I } \\
447 \\
458 \\
445 \\
439 \\
427 \\
432\end{array}$ \\
\hline 4 & Ryegrass (Italian) & $\begin{array}{r}3 \\
10 \\
11 \\
12\end{array}$ & $\begin{array}{l}843 \\
843 \\
827 \\
798\end{array}$ & $\begin{array}{l}870 \\
912 \\
911 \\
850\end{array}$ & $\begin{array}{l}534 \\
540 \quad(\text { IOI }) \\
505 \$(95) \\
517 \quad(97)\end{array}$ & $\begin{array}{l}187 \\
187 \\
185 \\
196\end{array}$ & $\begin{array}{l}431 \\
438 \\
432 \\
426\end{array}$ \\
\hline 5 & $\begin{array}{l}\text { Fescue (Festuca } \\
\text { arundinacea } \mathbf{L} \text {. var. } \\
\text { Alta) }\end{array}$ & $\begin{array}{l}2 \\
3 \\
4 \\
5 \\
6\end{array}$ & $\begin{array}{l}818 \\
804 \\
797 \\
811 \\
793\end{array}$ & $\begin{array}{l}898 \\
872 \\
865 \\
887 \\
847\end{array}$ & $\begin{array}{lr}517 & \\
513 & (99) \\
529 & (102) \\
4808 & (93) \\
489 & (95)\end{array}$ & $\begin{array}{l}179 \\
182 \\
187 \\
192 \\
203\end{array}$ & $\begin{array}{l}435 \\
439 \\
444 \\
440 \\
451\end{array}$ \\
\hline & $\begin{array}{l}\text { Standard error of } \\
\text { replication }\left(\begin{array}{ll}n & 20\end{array}\right)\end{array}$ & & 24 & 29 & 15 & 16 & 19 \\
\hline
\end{tabular}

* Protein calculated from the amino acid residues recovered, including ammonia, and applying a correction factor for tryptophan (see p. 457.)

$\dagger$ For details, see Table 1 .

$\ddagger$ For details, see p. 457 .

$\S$ Variation from batch control significant $(P<0.05)$.

gave FDNB-reactive lysine values which were significantly different from the batch control, but they did not show a significant difference from the batch control for the DBL values.

DBL plotted $v$. total lysine from amino acid analysis shows a high correlation $(r 0.91$, $n 28)$ as does a plot of FDNB-reactive lysine $v$. total lysine $(r 0.93, n 28)$ (see Figs. 1 and 2 respectively). This type of relationship was to be expected from earlier reports (Cranwell \& Haworth, I97I).

Table 3 shows the basic amino acids, glutamic acid and aspartic acid, which were determined by ion-exchange chromatography, together with an estimate of the standard error of replication of these observations based on ten duplicate samples of each. Aspartic acid and glutamic acid have been included because, under severe processing conditions, these amino acids have been shown to react with lysine to form isopeptides (Hurrell \& Carpenter, 1975). Only for one LPC sample (ryegrass sample no. 4) was aspartic acid significantly 


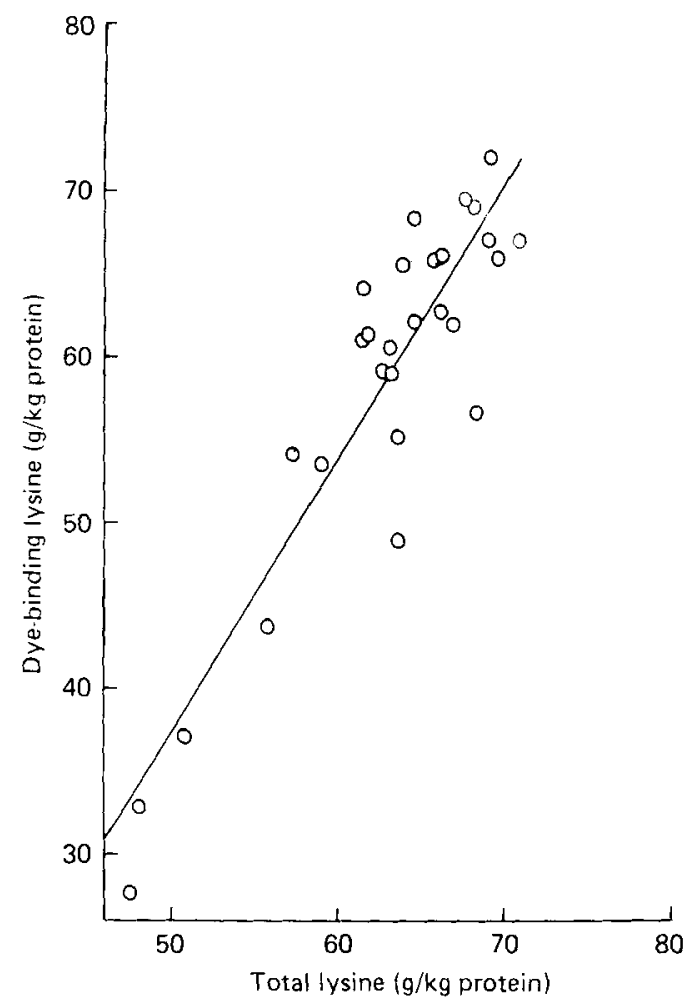

Fig. I. The relationship between dye-binding lysine $(\mathrm{g} / \mathrm{kg}$ protein (tungstic-acid-precipitated nitrogen $\times 6.25)$ ) and total lysine ( $/ \mathrm{kg}$ protein (for calculation, see $\mathrm{p} .457)$ ) by amino acid analysis of acid hydrolysates of twenty-eight leaf-protein concentrate samples subjected to different therma! treatments (for details of procedures and samples, see p. 456 and Table 1 respectively). $y=-45+\mathbf{I} \cdot 65 x$.

lower than that of the batch control, and glutamic acid values showed no differences in comparison with the control. For three LPC samples (lucerne samples nos. 19, 20 and 21) the aspartic acid was significantly higher than for the batch control. No explanation for the latter phenomenon can be given. The over-all lack of change of these two amino acids would indicate that lysine is not involved in the formation of isopeptides with glutamic acid and aspartic acid to any pronounced extent during the processing of the LPC samples studied, even for those severely heat-damaged at $110^{\circ}$ for 16 and $24 \mathrm{~h}$ (lucerne sample nos. 16 and 17 and ryegrass sample nos. 8 and 9). Table 3 also shows a significant decrease of total lysine when compared with batch controls for many of the heat-damaged LPC samples, which would be expected from results given in Figs. I and 2. Of the other two basic amino acids, only arginine showed a significant decrease on heating for some LPC samples in batch no. I.

Hurrell \& Carpenter (1975) showed that DBC was more closely correlated to histidine + arginine + FDNB-reactive lysine (HARL value) than to the total basic amino acids. DBC values for all LPC samples studied are here plotted $v$. (a) total basic amino acids (histidine, arginine and total lysine) (Fig. 3), (b) HARL value, calculated using the DBL value for reactive lysine (Fig. 4) and (c) HARL value, calculated using the FDNB-reactive lysine value (Fig. 5); $r$ values were nearly identical $(0.82,0.8 \mathrm{I}$ and 0.82 respectively). Thus, for 


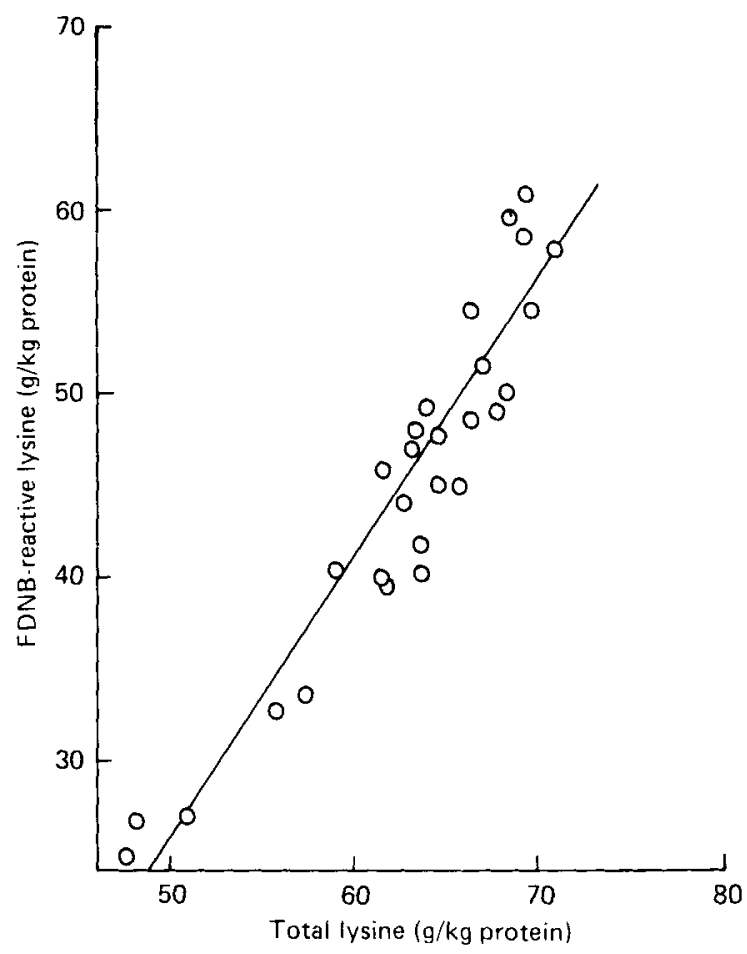

Fig. 2. The relationship between fluorodinitrobenzene (FDNB)-reactive lysine (g/kg protein (tungstic-acid-precipitated nitrogen $\times 6 \cdot 25)$ ) and total lysine $(\mathrm{g} / \mathrm{kg}$ protein (for calculation, see p. 457)) by amino acid analysis of acid hydrolysates for twenty-eight leaf-protein concentrate samples subjected to different thermal treatments (for details of procedures and samples, see $\mathbf{p}$. 456 and Table 1 respectively), $y=-51+1 \cdot 54 x$.

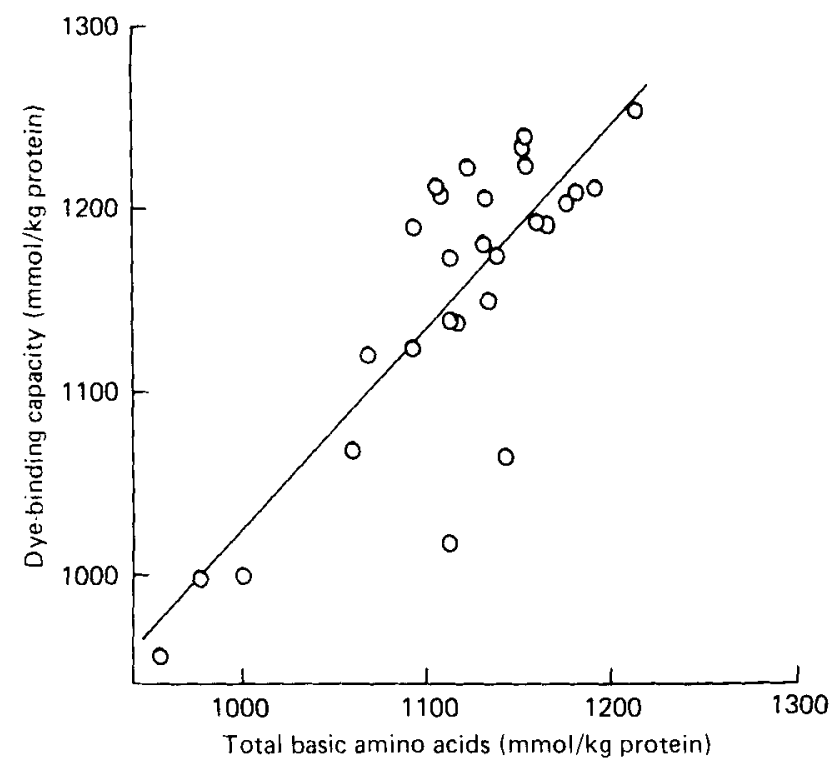

Fig. 3. The relationship between dye-binding capacity ( $\mathrm{mmol} / \mathrm{kg}$ protein (tungstic-acid-precipitated nitrogen $\times 6.25)$ ) and total basic amino acids (mmol/ $\mathrm{kg}$ protein (for calculation, see $\mathrm{p} .457)$ ) by amino acid analysis of acid hydrolysates of twenty-eight leaf-protein concentrate samples subjected to different thermal treatments (for details of procedures and samples, see p. 456 and Table 1 respectively). $y=-76+1 \cdot 10 x$. 


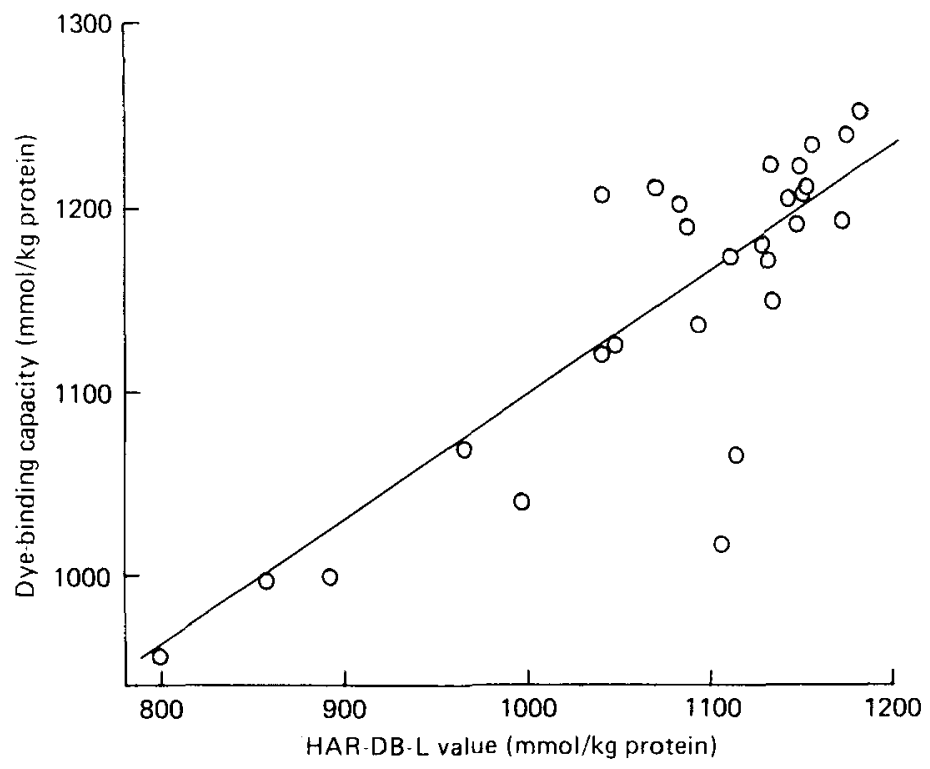

Fig. 4. The relation between dye-binding capacity ( $\mathrm{mmol} / \mathrm{kg}$ protein (tungstic-acid-precipitated nitrogen $\times 6 \cdot 25)$ ) and the histidine + arginine + dye-binding lysine (HAR-DB-L) value (mmol $/ \mathrm{kg}$ protein) for twenty-eight leaf-protein concentrate samples subjected to different thermal treatments (for details of procedures, calculation of HAR-DB-L value and details of samples, see p. 456 , p. 457 and Table I respectively). $y=419+0.68 x$.

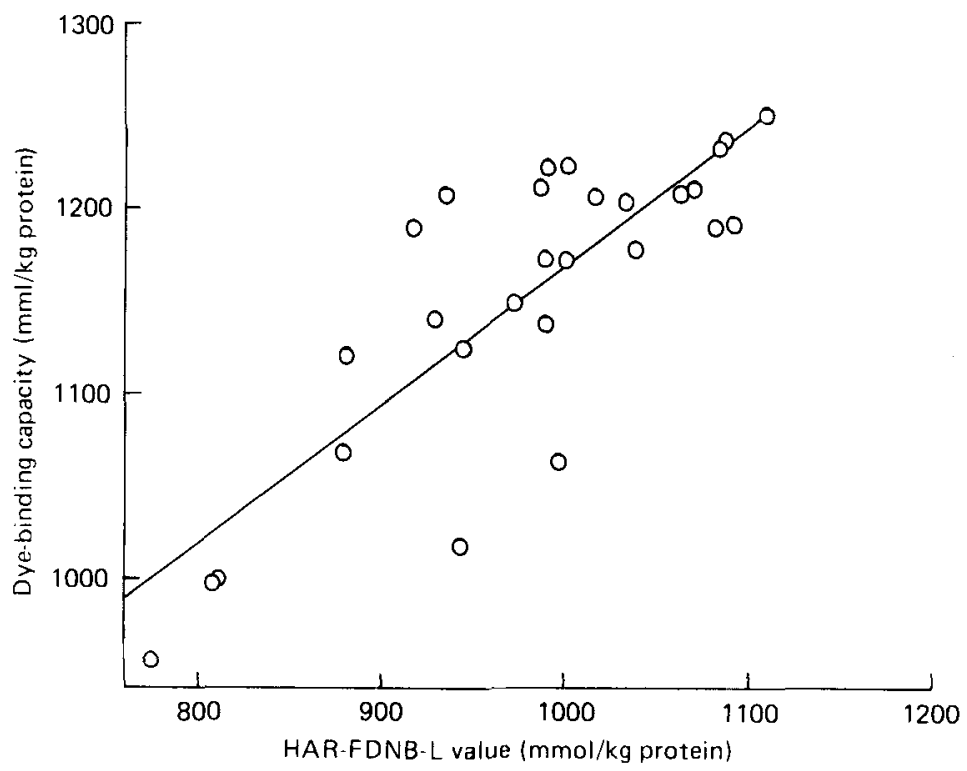

Fig. 5. The relation between dye-binding capacity (mmol $/ \mathrm{kg}$ protein (tungstic-acid-precipitated nitrogen $\times 6.25)$ ) and the histidine+arginine+fluorodinitrobenzene (FDNB)-reactive lysine (HAR-FDNB-L) value (mmol/kg protein) for twenty-eight leaf-protein concentrate samples subjected to different thermal treatments (for details of procedures, the calculation of HAR-FDNB-L value and details of samples, see p. 456 , p. 457 and Table I respectively). $y=417+0.75 x$. 


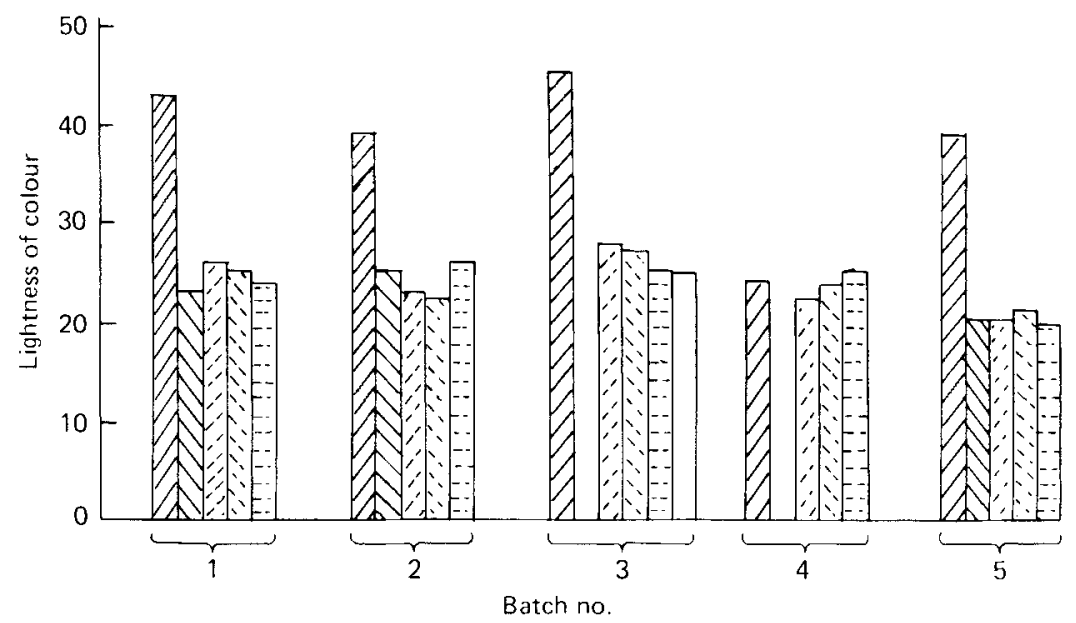

Fig. 6. Histogram to show lightness of colour (units of colour on $L, a, b$ scale (o, black; 100, white); see p. 457), using the Hunter Color Difference Meter for twenty-four leaf-protein concentrate samples from five curd batches, subjected to different thermal treatments. $Q$, Freeze-dried; $\square$, dried at room temperature; $\square$, dried by evaporation under reduced pressure; 8 , dried at $50^{\circ}$, overnight, forced-air oven; 3 , dried at $90^{\circ}$, overnight, forced-air oven; 面, dried at $90^{\circ}$, overnight, vacuum oven. For details of samples, see Table $\mathbf{I}$.

the LPC samples studied the HARL value holds no advantage over total basic amino acids for comparison with DBC.

Fig. 6 indicates the lightness of colour of the different batches of LPC samples. There was no correlation between the lightness of colour and the nutritional value as assessed by available lysine determined by either the DBL or FDNB-reactive methods.

The DBL method described here provides a convenient, reproducible and simple method for the estimation of reactive lysine as an indicator of processing damage to LPC samples, so long as suitable experimental conditions are chosen. There appears to be no reason why it should not be applied as successfully to other food materials, provided that there is no interference from other food components. If this is so then the DBL method could be used as a quality control measurement during food processing. The simplicity of the methodology makes it very suitable for use in laboratories lacking sophisticated equipment.

Grateful acknowledgement is made to the Wolfson Foundation for financial assistance, to Dr C. Humphries and Mr J. Dick for help in preparation of samples, to Messrs N. Ward, K. Westcott and S. Wilkinson of the Department of Agriculture, University of Reading for the extraction of leaf juice, to Mr R. Mead and Dr R. D. Stern for advice on statistical analysis, to Miss C. M. Marshall for some of the FDNB-reactive lysine analyses and to Dr A. L. Lakin for advice and encouragement.

\section{REFERENCES}

Allison, R. M., Laird, W. M. \& Synge, R. L. M. (1973). Br. J. Nutr. 29, 5 I.

Bickoff, E. M., Booth, A. N., de Fremery, D., Edwards, R. H., Knuckles, B. E., Miller, R. E., Saunders,

R. M. \& Kohler, G. O. (1975). In Protein Nutritional Quality of Foods and Feeds, part 2, p. 3I9 [M.

Friedman, editor]. New York: Marcel Dekker Inc.

Boctor, A. M. \& Harper, A. E. (1968). J. Nutr. 94, 289.

Booth, V. H. (1971). J. Sci. Fd Agric. 22, 658.

Bray, W. J. \& Humphries, C. (1978). J. Sci. Fd Agric. 29, 839.

Byers, M. (1971). J. Sci. Fd Agric. 22, 242. 
Carpenter, K. J. (1960). Biochem. J. 77,604.

Carpenter, K. J. \& Woodham, A. A. (1974). Br. J. Nutr. 32, 647.

Cranwell, P. A. \& Haworth, R. D. (197I). Tetrahedron 27, 1831.

Davys, M. N. G. \& Pirie, N. W. (1960). Engineering 190, 274.

Davys, M. N. G. \& Pirie, N. W. (1965). J. agric. Engng Res. 10, 142.

Fisher, H. (1974). In Nutrients in Processed Foods - Proteins, p. 77. [P. L. White and D. C. Fletcher, editors]. Acton, Massachusetts: Publishing Sciences Group Inc.

Ford, J. E. (1964). Br. J. Nutr. 18, 449.

Henry, K. M. (1964). Proc. 6th int. Nutr. Congr. 1963, p. 492.

Henry, K. M. \& Ford, J. E. (1965). J. Sci. Fd Agric. 16, 425.

Hurrell, R. F. \& Carpenter, K. J. (1975). Br. J. Nutr. 33, IOI.

Hurrell, R. F. \& Carpenter, K. J. (1976). Proc. Nutr. Soc. 35, 23 A.

Hurrell, R. F. \& Carpenter, K. J. (1978). J. Agric. Fd Chem. 26, 796.

Hurrell, R. F., Carpenter, K. J., Sinclair, W. J., Otterburn, M. S. \& Asquith, R. S. (1976). Br. J. Nutr. 35, 383 .

Jokinen, J. E. \& Reineccius, G. A. (1976). J. Fd Sci. 4I, 8I6.

Lea, C. H. \& Hannan, R. S. (1950). Biochim. biophys. Acta 5, 433.

Mossberg, R. (1966). Agric. hort. Genet. 24, 193.

Perry, D. R. \& Adams, W. A. (1971). Biochem. J. 125, 29 P.

Pirie, N. W. (I971) (editor). Leaf Protein: its Agronomy, Preparation, Quality and Use. I.B.P. Handbook no. 20. Oxford: Blackwell Scientific Publications.

Roach, A. G., Sanderson, P. \& Williams, D. R. (1967). J. Sci. Fd Agric. 18, 274.

Shurpalekar, K. S., Singh, N. \& Sundaravalli, O. E. (1966). Proc. 7th int. Nutr. Congr. 3, 285.

Walker, A. F. (1979). Br. J. Nutr. 42, 445. 